\title{
Randomized Controlled Trial
}

\section{Results of 2-Year Follow-Up of a Randomized, Double-Blind, Controlled Trial of Fluoroscopic Caudal Epidural Injections In Central Spinal Stenosis}

Laxmaiah Manchikanti, MD ${ }^{1,2}$, Kimberly A. Cash, RT ${ }^{1}$, Carla D. McManus, RN, BSN ${ }^{1}$, Vidyasagar Pampati, $\mathrm{MSc}^{2}$, and Bert Fellows, $\mathrm{MA}^{1}$

From: Pain Management Center of Paducah, Paducah, KY; and University of Louisville, Louisville,

Dr. Manchikanti is Medical Director of the Pain Management

Center of Paducah, Paducah,

KY and Clinical Professor, Anesthesiology and Perioperative Medicine, University of Louisville, Louisville, KY

Kimberly A. Cash is a Research Coordinator at the Pain Management Center of Paducah, Paducah, KY

Carla D. McManus is a Nursing

Administrator at the Pain Management Center of Paducah, Paducah, KY

Vidyasagar Pampati is a Statistician at the Pain Management Center of Paducah, Paducah, KY

Bert Fellows is Director Emeritus

of Psychological Services at the

Pain Management Center of

Paducah, Paducah, KY

Address Correspondence: Laxmaiah Manchikanti, MD 2831 Lone Oak Road

Paducah, Kentucky 42003 E-mail:drlm@thepainmd.com

Disclaimer: There was no external funding in the preparation of this manuscript.

Conflict of interest: None.

Manuscript received: 08/10/2012 Accepted for publication: 09/12/2012

Free full manuscript: www.painphysicianjournal.com
Background: Lumbar spinal stenosis is one of the most common causes of low back pain among older adults and can cause significant disability. Despite its prevalence, there is a paucity of literature concerning the treatment of spinal stenosis symptoms. Multiple interventions, including surgery and interventional techniques such as epidural injections and adhesiolysis, are commonly utilized in managing pain related to central spinal stenosis. However, there is a paucity of literature from randomized, controlled trials about the effectiveness of epidural injections for lumbar central spinal stenosis.

Objective: This study sought to assess the effectiveness of caudal epidural injections with or without steroids in providing effective and long-lasting pain relief for the management of chronic low back pain related to lumbar central stenosis.

Study Design: A randomized, double-blind, active-controlled trial.

Methods: One hundred patients were randomly assigned to one of 2 groups, with Group I patients receiving caudal epidural injections of local anesthetic (lidocaine $0.5 \%$ ), whereas Group II patients received caudal epidural injections with $0.5 \%$ lidocaine $9 \mathrm{~mL}$ mixed with $1 \mathrm{~mL}$ of steroid, $6 \mathrm{mg}$ (non-particulate betamethasone).

Outcomes Assessment: Multiple outcome measures, including the Numeric Pain Rating Scale (NRS), the Oswestry Disability Index 2.0 (ODI), employment status, and opioid intake were utilized. Assessments were carried out at 3, 6, 12, 18, and 24 months posttreatment.

The primary outcome was defined as pain relief and improvement in disability scores of $50 \%$ or more. Successful treatment was considered as at least 3 weeks of relief following the first 2 injections, categorizing these patients into a successful group, and others into a failed group.

Results: Significant pain relief and functional status improvement were seen in $51 \%$ in Group I and $57 \%$ in Group II at the end of 2 years in the successful group when the participants were separated into successful and failed groups. However, overall, significant pain relief and functional status improvement ( $\geq 50 \%$ ) was demonstrated in 38\% in Group I and $44 \%$ in Group II at the end of 2 years. The overall number of procedures for 2 years were 4 in both groups, with 5 procedures on average in the successful groups, and approximately 60 weeks of relief in Group I and 54 weeks of relief in Group II at 2 years in the successful group.

Conclusion: Caudal epidural injections of local anesthetic with or without steroids provide relief in a modest proportion of patients undergoing the treatment and may be considered as an effective treatment for a select group of patients who have chronic function-limiting low back and lower extremity pain secondary to central spinal stenosis.

Key Words: Low back pain, lower extremity pain, spinal stenosis, epidural injections, steroids, local anesthetics

CLINICAL TRIAL: NCT00370799

Pain Physician 2012; 15:371-384 


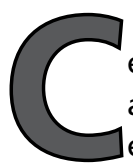
entral lumbar spinal stenosis is defined as a narrowing of the spinal canal with encroachment on the neural structures by surrounding bone and soft tissue, usually caused by spinal degenerative conditions, resulting in significant disability (1-4). However, the causes of spinal stenosis are often multifactorial and the clinical presentation can be variable, and have a lack of correlation with radiographic findings $(5,6)$. The symptoms of lumbar central stenosis range from low back or buttock pain or discomfort to pain and weakness in lower extremities precipitated by walking and prolonged standing (7). Spinal stenosis has been shown to be prevalent in $27.2 \%$ of the population in the Framingham study (2). Spinal stenosis is one of the 3 most common diagnoses of low back and leg pain for which surgery is performed, along with intervertebral disc herniation and degenerative spondylolisthesis (8-13). However, lumbar spinal stenosis has been described as the most frequent indication for spine surgery in patients older than 65 years of age $(8,11-13)$. Numerous modalities of treatments have been advocated in managing lumbar central spinal stenosis, including not only surgery with or without fusion, but also interventional techniques and conservative modalities $(3,4,11,14-37)$. Lumbar spinal stenosis is often associated with poor patient health outcomes and functioning, high resource utilization, and substantial health system expenses (4).

The rate of fusion for spinal stenosis has been exploding. Between 2002 and 2007, the frequency of complex fusion procedures for spinal stenosis increased 15-fold from 1.3 to 19.9 per 100,000 Medicare beneficiaries (11). In addition, randomized trials indicate that for severely affected patients, surgery offers greater efficacy than nonsurgical treatments $(3,14,15)$. It has also been shown that multilevel lumbar spinal stenosis without associated degenerative spondylolisthesis or scoliosis can be managed nonoperatively irrespective of the number of levels involved (37). However, in this report, the authors also concluded that if surgery is performed, the number of levels treated does not predict outcome. Thus, even though the results of surgery may be encouraging in severe symptomatic stenosis, the results for patients with mild and moderate stenosis are not well known. They may not only not be candidates for decompressive surgery or fusion, but they may not respond well, and the effects of surgery tend to deteriorate. Next to surgery, epidural injections are one of the most commonly performed interventions for managing chronic low back pain secondary to central spinal stenosis (16,23-35). However, in reference to central spinal stenosis, only one randomized trial has been published thus far with appropriate outcome parameters and fluoroscopic guidance of the epidural injections (16).

This study showed significant improvement in $60 \%$ of the patients in the successful group at one year follow-up, whereas overall, the results were $44 \%$ of patients receiving local anesthetic only and $46 \%$ of patients receiving local anesthetic and steroids, and $60 \%$ of patients receiving either local anesthetic alone or with steroids. A randomized, double-blind trial of percutaneous adhesiolysis after failed epidural injections has shown significant pain relief in $76 \%$ of the patients at one-year follow-up in the adhesiolysis group compared to $4 \%$ of the patients in the control group (35).

In designing a study protocol for lumbar epidural steroid injections for spinal stenosis, Friedly et al (4) described that there was only one early randomized controlled trial (38) which showed no advantage for epidural steroid injections over saline or local anesthetic injections. They also considered the study by Manchikanti et al (39); however, this was a preliminary report of the study, and they misinterpreted the results. They also failed to consider the one-year follow-up which was available at the time of publication (16). For the preliminary report, they described that the study suffered significant methodological limitations, including a lack of statistical power, no primary outcome measure, unblinding of patients and researchers, and a high dropout rate (21/60 patients). However, their assessment was disappointing in that they utilized the number of patients who had not finished their oneyear follow-up as dropouts. Further, this (39) was a preliminary publication. Consequently, there was no statistical power. However, primary outcome measures were clearly described and there was no unblinding of patients and researchers. This essentially illustrates the state of evidence-based medicine and comparative effectiveness research with inappropriate methodology and assessment and failure to correct such erroneous assumptions $(27,40-46)$.

However, interventional techniques may be medically indicated and cost-effective as an initial therapy, when there is appropriate selection of the patients and contemporary administration of the intervention. Kuntz et al (47), in an analysis of 10-year cost and health outcomes for persons with stenosis, showed reasonable value for noninstrumented fusion related to laminec- 
tomy alone, but unfavorable value for instrumented fusion. The analysis of cost effectiveness after 2 years of the Spine Patient Outcomes Research Trials study (commonly known as SPORT) (15) also showed that stenosis surgeries improved health to a greater extent than nonoperative care, at a cost of $\$ 77,600$ for a quality-of-life year gained.

Epidural steroid injections are administered by 3 approaches. They are caudal, interlaminar, and transforaminal (32-34). While the majority of the negative evidence for epidural injections has been derived from old studies performed without fluoroscopy, or poorly designed studies, recent evaluations (32-34) have shown significantly different evidence, especially considering those epidural injections performed in contemporary interventional pain management practices with fluoroscopy. Even then, the trials comparing surgical with nonsurgical treatments, specifically epidural injections and trials comparing epidural injections with conservative management, have generally been small and also involved multiple confounding factors with patients suffering not only with spinal stenosis, but also degenerative spondylolisthesis $(8,15,48-51)$.

This study was undertaken to evaluate the role of caudal epidural injections with or without steroids on the significant pain relief and functional status improvement of patients with chronic intractable pain secondary to spinal stenosis. This 2-year follow-up report is an extension of a preliminary report of one-year results previously published (16).

\section{Methods}

The study was conducted in an interventional pain management practice, a specialty referral center, in a private practice setting in the United States, and was based on Consolidated Standards of Reporting Trials (commonly known as CONSORT) guidelines (52). The study protocol was approved by the Institutional Review Board (IRB) and was registered with the U.S. Clinical Trial Registry with an assigned number of NCT00370799. This study was conducted with the internal resources of the practice without any external funding, either from industry or from elsewhere.

\section{Patients}

One hundred patients were recruited from a single pain management program and were assigned to one of 2 groups. They were given the IRB-approved protocol and informed consent which described in detail all aspects of the study and withdrawal process.

\section{Interventions}

Of the 100 patients, 50 patients were assigned to Group I, who received caudal epidural injections of local anesthetic (lidocaine $0.5 \%$ preservative-free). Group II (50 patients) received caudal epidural injections of $0.5 \%$ lidocaine, $9 \mathrm{~mL}$, mixed with $1 \mathrm{~mL}$ of nonparticulate betamethasone, $6 \mathrm{mg}$. A total volume of 10 $\mathrm{mL}$ was injected in each patient, followed by an injection of $2 \mathrm{~mL}$ of $0.9 \%$ sodium chloride solution to flush the contents from the sacral canal.

\section{Pre-enrollment Evaluation}

Demographic data, medical and surgical history with co-existing disease(s), radiologic investigations, physical examination, pain rating scores using the $\mathrm{Nu}$ meric Rating Scale (NRS), work status, opioid intake, and functional status assessment using the Oswestry Disability Index 2.0 (ODI) were assessed prior to enrollment.

\section{Inclusion and Exclusion Criteria}

Only those patients with central spinal stenosis with radicular pain of at least 6 months duration were included. Other criteria were that pain must have been function-limiting, 30 years or older, and the ability to understand the study protocol and provide voluntary, written informed consent and participate in outcome measurement. Another inclusion criterion included failed conservative management.

However, patients with a history of uncontrollable or unstable opioid use, uncontrolled psychiatric disorders, uncontrolled medical illness, those suffering with conditions that could interfere with the interpretation of outcome assessments, pregnant or lactating women, and those with a history or potential for adverse reactions to lidocaine or betamethasone were excluded.

\section{Description of Interventions}

One physician performed all epidural injections under fluoroscopy in an ambulatory surgery center, in a sterile operating room. The patients were in the prone position with appropriate monitoring with intravenous access and sedation with midazolam and fentanyl as indicated. Access to the epidural space was obtained utilizing a sterile technique, confirmed by injection of non-ionic contrast medium. After confirmation of the epidural space, an injection of local anesthetic, with or without betamethasone, was administered, followed by an injection of $2 \mathrm{~mL}$ of $0.9 \%$ sodium chloride solution. 


\section{Additional Interventions}

Treatments were given to patients as assigned. Upon request, or if an emergency situation arose, a patient would be unblinded. Based on a patient's response to prior caudal epidural injections, and improvement in physical and functional status, repeat caudal epidural injections were administered when increased levels of pain were reported with deteriorating relief below $50 \%$. Unresponsive patients were treated with conservative management and were followed without further epidural injections with medical management, without unblinding.

\section{Co-Interventions}

Conservative management utilized by the majority of the patients prior to the interventions included opioid, nonopioid, and adjuvant analgesics and/or a therapeutic exercise program. All these were continued. However, medication adjustments were made based on the medical necessity and indications. Therapeutic exercises and continuation of employment were stressed.

\section{Objectives}

The study was designed to assess the effectiveness of caudal epidural injections with or without steroids in managing chronic low back pain with radiculitis secondary to spinal stenosis with long-term follow-up.

\section{Outcomes}

Multiple outcome measures were utilized which included the NRS (0-10 scale) pain scale, the ODI on a 0-50 scale, employment status, and opioid intake in terms of morphine equivalents, with assessment at 3,6 , 12,18 , and 24 months posttreatment.

The value and validity of the NRS and ODI have been reported $(40,53,54)$. Due to the criticism of outcome measurements and their insignificance (53-55), a robust measure of improvement with significant pain relief and reduction in disability of $50 \%$ or more have been utilized in multiple studies and adapted to this study (56-74). Opioid intake was converted into a morphine equivalence (75).

The primary outcome was defined as a significant improvement of $50 \%$ or more reduction in the NRS or ODI scores.

Patients responding with relief lasting at least 3 weeks with any of the first 2 procedures were considered to be in the successful category. All others were considered as failures.
The criterion for work status was based on the status at the time of enrollment. Employment categories included: employable, housewife with no desire to work outside the home, retired, and over age 65 . Those unemployed because of pain, on sick leave, or laid off were considered employable.

\section{Sample Size}

The sample size was calculated based on significant pain relief. Considering a 0.052 -sided significance level, a power of $80 \%$, and an allocation ratio of $1: 1$, 18 patients in each group were estimated (76). Allowing for a $10 \%$ attrition/noncompliance rate, 40 patients were required.

\section{Randomization}

Fifty patients were assigned to each group randomly from a total of 100 patients.

\section{Sequence Generation}

A computer-generated simple random allocation sequence was utilized.

\section{Allocation Concealment}

Patient randomization and drug preparation was done by one of the 3 study coordinators, without knowledge of the patient, physician, or other personnel.

\section{Implementation}

All patients meeting the inclusion criteria were invited to participate. They were enrolled and assigned to a group by a nurse coordinator.

\section{Blinding (Masking)}

Group assignments were blinded to all investigators. Study patients were mixed with routine treatment patients.

\section{Statistical Methods}

For testing the differences in proportions, chisquared statistic was used. Wherever the expected value was less than 5, Fisher's exact test was used; a paired t-test was used to compare the pre- and post treatment results of average pain scores and ODI measurements at baseline versus $3,6,12,18$, and 24 months. T-test was performed to compare mean scores between groups. A $P$ value of 0.05 was considered as significant. Because the outcome measures of the participants were measured at 6 points in time, repeated measures analysis of variance were performed with the post hoc analysis. 
Intent-to-Treat-Analysis

An intent-to-treat-analysis was performed. Either the last follow-up data or initial data were utilized in the patients who dropped out of the study or no other data were available. A sensitivity analysis with changes in the NRS was performed utilizing the last follow-up score, best case scenario, and worst case scenario. If there were no significant differences; the intention-totreat analysis with last follow-up visit was used.

\section{Results}

\section{Participant Flow}

Figure 1 illustrates the participant flow.

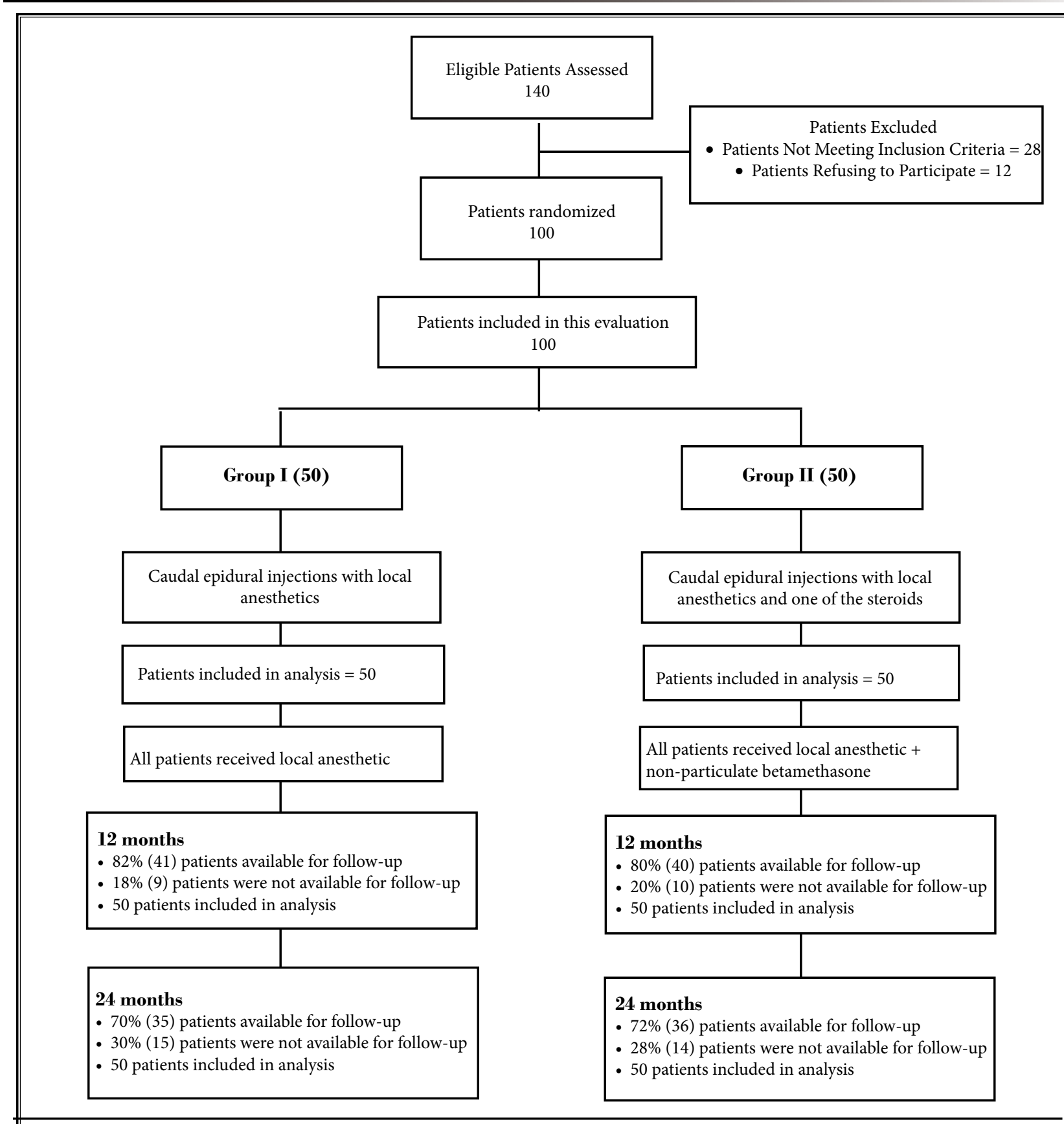

Fig. 1. Schematic presentation of patient flow at 2-year follow-up. 
Table 1. Baseline demographic and clinical characteristics.

\begin{tabular}{|c|c|c|c|c|}
\hline & & $\begin{array}{c}\text { Group } 1 \\
(\mathbf{5 0})\end{array}$ & $\begin{array}{c}\text { Group II } \\
(\mathbf{5 0})\end{array}$ & $P$ value \\
\hline \multirow{2}{*}{ Gender } & Male & $32 \%(16)$ & $50 \%(25)$ & \multirow{2}{*}{0.103} \\
\hline & Female & $68 \%(34)$ & $50 \%(25)$ & \\
\hline Age & Mean \pm SD & $56.9 \pm 14.5$ & $55.7 \pm 15.9$ & 0.714 \\
\hline Weight & Mean \pm SD & $195 \pm 52.4$ & $187 \pm 47.3$ & 0.419 \\
\hline Height & Mean \pm SD & $66.0 \pm 3.7$ & $67.4 \pm 3.8$ & 0.069 \\
\hline Duration of Pain (months) & Mean \pm SD & $94.2 \pm 106.9$ & $104.9 \pm 80.4$ & 0.479 \\
\hline \multirow{2}{*}{ Onset of the Pain } & Gradual & $76 \%(38)$ & $74 \%(37)$ & \multirow{2}{*}{1.000} \\
\hline & Injury & $24 \%(12)$ & $26 \%(13)$ & \\
\hline \multirow{2}{*}{ Pain Distribution } & Bilateral & $80 \%(40)$ & $70 \%(35)$ & \multirow{2}{*}{0.356} \\
\hline & Left or Right & $20 \%(10)$ & $30 \%(15)$ & \\
\hline Numeric Rating Score & Mean \pm SD & $7.9 \pm 0.9$ & $7.6 \pm 0.8$ & 0.073 \\
\hline Oswestry Disability Index & Mean \pm SD & $39.8 \pm 4.2$ & $28.1 \pm 4.6$ & 0.062 \\
\hline
\end{tabular}

Table 2. Spinal stenosis: Severity and involved level(s) as classified by radiologist(s) (MRI or CT scan).

\begin{tabular}{|c|c|c|c|c|c|c|c|c|c|c|c|c|c|}
\hline & \multirow[t]{2}{*}{ Group } & \multicolumn{4}{|c|}{ Severe } & \multicolumn{4}{|c|}{ Moderate } & \multicolumn{4}{|c|}{ Mild } \\
\hline & & L2/3 & L3/4 & L4/5 & L5/S1 & L2/3 & L3/4 & L4/5 & L5/S1 & L2/3 & L3/4 & L4/5 & L5/S1 \\
\hline \multirow[t]{3}{*}{ Primary $^{*}$} & I & 1 & 3 & 5 & 3 & 1 & 8 & 15 & 8 & 3 & 8 & 15 & 7 \\
\hline & II & 0 & 3 & 10 & 4 & 1 & 5 & 15 & 4 & 2 & 2 & 12 & 6 \\
\hline & Total & 1 & 6 & 15 & 7 & 2 & 13 & 30 & 12 & 5 & 10 & 27 & 13 \\
\hline \multirow[t]{3}{*}{ Secondary } & I & 0 & 0 & 0 & 0 & 0 & 2 & 1 & 0 & 2 & 5 & 5 & 2 \\
\hline & II & 0 & 0 & 0 & 0 & 1 & 6 & 4 & 0 & 0 & 4 & 2 & 3 \\
\hline & Total & 0 & 0 & 0 & 0 & 1 & 8 & 5 & 0 & 2 & 9 & 7 & 5 \\
\hline
\end{tabular}

${ }^{\star}$ Primary - Indicates worst level of stenosis or same type stenosis at multiple levels in patients with multiple level stenosis and all patients with single level stenosis.

Table 3. Number of stenosis levels involved in the study population.

\begin{tabular}{|l|c|c|c|}
\hline & Group I & Group II & Total \\
\hline One Level & 19 & 20 & 39 \\
\hline Two Levels & 20 & 25 & 45 \\
\hline Three Levels & 9 & 4 & 13 \\
\hline Four Levels & 2 & 1 & 3 \\
\hline
\end{tabular}

\section{Recruitment}

Enrollment period lasted from January 2007 to December 2009.

\section{Baseline Data}

Table 1 shows baseline characteristics. Tables 2 and 3 illustrate severity and levels of spinal stenosis.

\section{Therapeutic Procedural Characteristics}

As shown in Table 4, at 2-year follow-up, Group I had an average overall pain relief of $44.6 \pm 42.3$ weeks; whereas Group II patients reported $41.5 \pm 40.5$ weeks of relief. However, when participant were separated into successful and failed categories, the relief was $59.6 \pm$ 40.41 weeks in Group I and $54.2 \pm 38.3$ weeks in Group II in the successful categories at 2-year follow-up. The average number of procedures was $5.1 \pm 2.6$ per 2 years in Group I and $4.5 \pm 2.3$ in Group II in the successful categories. In contrast, in the failed category, the number of procedures per 2 years was $1.7 \pm 0.6$ in Group I and $1.6 \pm 1.4$ in Group II.

\section{Outcomes}

\section{Pain Relief and Functional Improvement}

Table 5 and Figure 2 illustrate the proportion of participants with a significant change in pain and func- 
Table 4. Therapeutic procedural characteristics with procedural frequency, average relief per procedure, and average total relief in weeks over a period of 2 years.

\begin{tabular}{|c|c|c|c|c|c|c|}
\hline & \multicolumn{2}{|c|}{ Successful subjects } & \multicolumn{2}{|c|}{ Failed subjects } & \multicolumn{2}{|c|}{ Combined } \\
\hline & $\begin{array}{l}\text { Group I } \\
(37)\end{array}$ & $\begin{array}{l}\text { Group II } \\
(\mathbf{3 7})\end{array}$ & $\begin{array}{l}\text { Group I } \\
\text { (13) }\end{array}$ & $\begin{array}{l}\text { Group II } \\
\text { (13) }\end{array}$ & $\begin{array}{l}\text { Group I } \\
\quad(\mathbf{5 0})\end{array}$ & $\begin{array}{l}\text { Group II } \\
\quad(50)\end{array}$ \\
\hline \multicolumn{7}{|l|}{ Procedural details } \\
\hline Average number of procedure per one year & $3.6 \pm 1.1$ & $3.5 \pm 1.2$ & $1.7 \pm 0.6$ & $1.4 \pm 0.7$ & $3.1 \pm 1.3$ & $2.9 \pm 1.4$ \\
\hline Total Number of injection in one year & 133 & 128 & 22 & 18 & 155 & 146 \\
\hline Average number of procedure per two years & $5.1 \pm 2.6$ & $4.5 \pm 2.3$ & $1.7 \pm 0.6$ & $1.6 \pm 1.4$ & $4.2 \pm 2.7$ & $3.8 \pm 2.4$ \\
\hline Total Number of injection in two years & 189 & 168 & 22 & 21 & 211 & 189 \\
\hline \multicolumn{7}{|l|}{ Relief details } \\
\hline $\begin{array}{l}\text { Average relief per procedure for initial } 2 \text { procedures } \\
\text { in weeks }\end{array}$ & $10.1 \pm 15.4$ & $8.11 \pm 12.4$ & $1.2 \pm 2.0$ & $1.0 \pm 1.8$ & $8.1 \pm 14.0$ & $6.8 \pm 11.6$ \\
\hline $\begin{array}{l}\text { Average relief per procedure after initial } 2 \\
\text { procedures }\end{array}$ & $12.7 \pm 6.7$ & $15.0 \pm 10.9$ & 0.0 & $12.8 \pm 1.3$ & $12.6 \pm 6.8$ & $14.9 \pm 10.7$ \\
\hline Average relief per injection & $11.7 \pm 10.9$ & $11.9 \pm 12.1$ & $1.1 \pm 2.0$ & $3.2 \pm 5.0$ & $10.6 \pm 10.9$ & $11.0 \pm 11.8$ \\
\hline Average total relief per one year (weeks) & $34.0 \pm 16.3$ & $31.7 \pm 17.5$ & $1.9 \pm 2.4$ & $2.1 \pm 4.7$ & $25.6 \pm 19.9$ & $24.0 \pm 20.0$ \\
\hline Average total relief per two years (weeks) & $59.6 \pm 40.1$ & $54.2 \pm 38.8$ & $1.9 \pm 2.4$ & $5.2 \pm 15.6$ & $44.6 \pm 42.3$ & $41.5 \pm 40.5$ \\
\hline
\end{tabular}

\# indicates significant difference group II $(\mathrm{p}<0.05)$

Successful subject : At least 3 weeks of relief following the first 2 injections

Table 5. Comparison of Numeric Pain Rating Scale for pain and Oswestry Disability Index score summaries at six time points (lower value indicates better condition).

\begin{tabular}{|c|c|c|c|c|}
\hline \multirow[t]{2}{*}{ Numeric Rating Score } & \multicolumn{2}{|c|}{ Numeric Pain Rating scale } & \multicolumn{2}{|c|}{ Oswestry Disability Index } \\
\hline & $\begin{array}{c}\text { Group I (50) } \\
\text { Mean } \pm \text { SD }\end{array}$ & $\begin{array}{c}\text { Group II (50) Mean } \\
\pm \text { SD }\end{array}$ & $\begin{array}{c}\text { Group I (50) } \\
\text { Mean } \pm \text { SD }\end{array}$ & $\begin{array}{c}\text { Group II (50) } \\
\text { Mean } \pm \text { SD }\end{array}$ \\
\hline Baseline & $7.9 \pm 0.9$ & $7.6 \pm 0.8$ & $29.8 \pm 4.2$ & $28.1 \pm 4.6$ \\
\hline 3 months & $\begin{array}{c}4.1^{*} \pm 1.8 \\
(66 \%)\end{array}$ & $\begin{array}{c}4.1^{*} \pm 1.9 \\
(62 \%)\end{array}$ & $\begin{array}{c}17.2^{*} \pm 6.8 \\
(58 \%)\end{array}$ & $\begin{array}{c}16.8^{*} \pm 7.9 \\
(49 \%)\end{array}$ \\
\hline 6 months & $\begin{array}{c}4.1^{*} \pm 1.7 \\
(58 \%)\end{array}$ & $\begin{array}{c}4.2^{*} \pm 1.9 \\
(56 \%)\end{array}$ & $\begin{array}{c}17.2^{*} \pm 7.3 \\
(54 \%)\end{array}$ & $\begin{array}{c}16.9^{*} \pm 8.2 \\
(50 \%)\end{array}$ \\
\hline 12 months & $\begin{array}{c}4.4^{*} \pm 1.8 \\
(48 \%)\end{array}$ & $\begin{array}{c}4.3^{*} \pm 2.0 \\
(46 \%) \\
\end{array}$ & $\begin{array}{c}17.5^{*} \pm 7.6 \\
(50 \%)\end{array}$ & $\begin{array}{c}16.9^{*} \pm 7.8 \\
(50 \%)\end{array}$ \\
\hline 18 months & $\begin{array}{c}4.5^{*} \pm 1.8 \\
(44 \%)\end{array}$ & $\begin{array}{c}4.4^{*} \pm 2.0 \\
(48 \%)\end{array}$ & $\begin{array}{c}17.6^{*} \pm 7.2 \\
(42 \%)\end{array}$ & $\begin{array}{c}16.7^{*} \pm 7.9 \\
(48 \%)\end{array}$ \\
\hline 24 months & $\begin{array}{c}4.6^{*} \pm 1.8 \\
(42 \%)\end{array}$ & $\begin{array}{c}4.7^{*} \pm 2.2 \\
(44 \%)\end{array}$ & $\begin{array}{c}17.5^{*} \pm 7.3 \\
(42 \%)\end{array}$ & $\begin{array}{c}17.0^{*} \pm 7.6 \\
(46 \%)\end{array}$ \\
\hline Group Difference & \multicolumn{2}{|c|}{0.795} & \multicolumn{2}{|c|}{0.598} \\
\hline Baseline vs follow-up points & \multicolumn{2}{|c|}{0.000} & \multicolumn{2}{|c|}{0.000} \\
\hline Group by Time Interaction\# & \multicolumn{2}{|c|}{0.726} & \multicolumn{2}{|c|}{0.572} \\
\hline
\end{tabular}

Percentages in parenthesis illustrates proportion with significant pain relief $(\geq 50 \%)$ from baseline

* indicates significant difference with baseline values $(\mathrm{P}<0.05)$

\# Group by Time Interaction - There were no significant difference between groups at 3 months, 6 months, 12 months, 18 months and 24 months. 


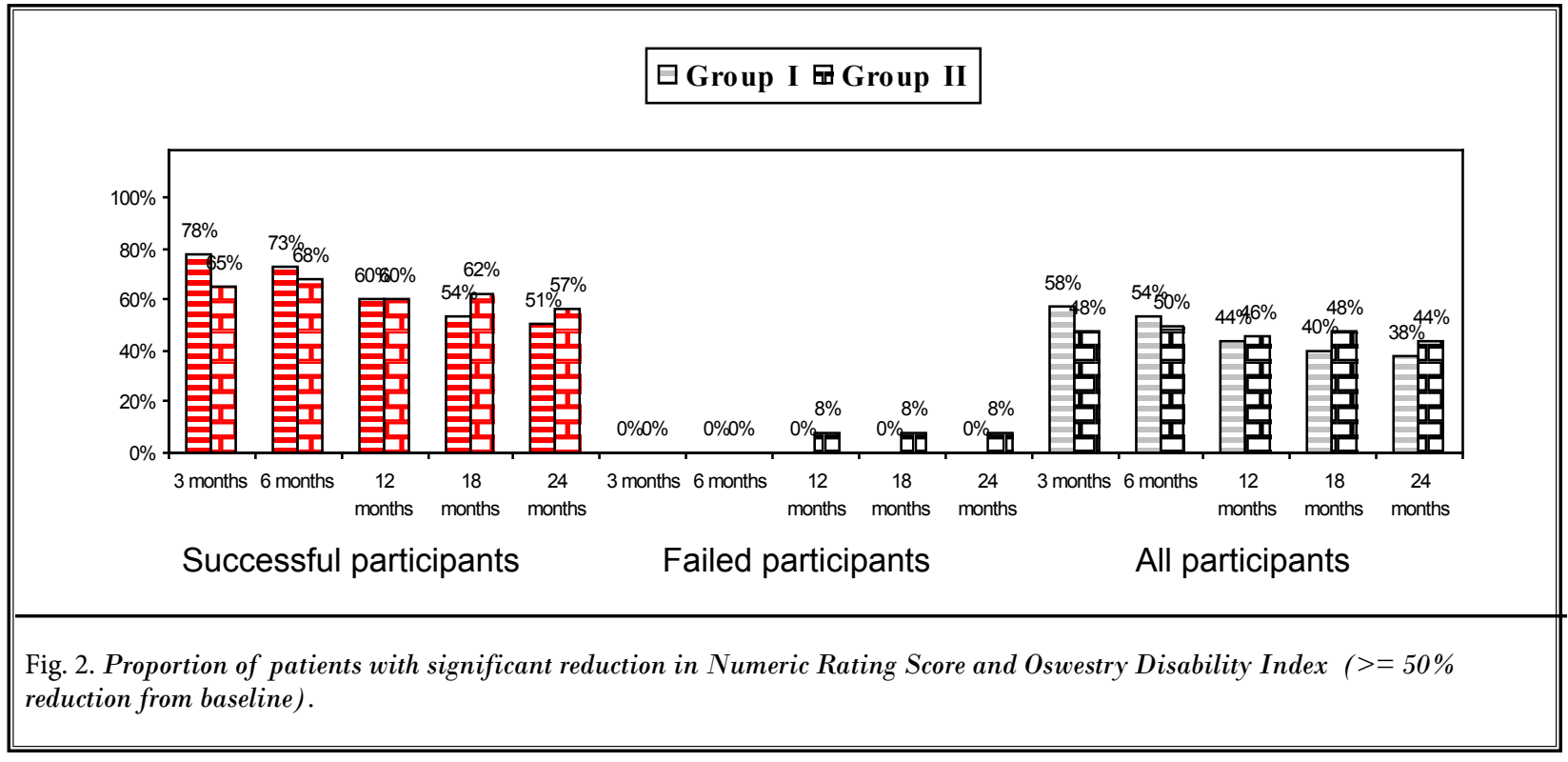

Table 6. Employment characteristics.

\begin{tabular}{|l|c|c|c|c|c|c||}
\hline \multirow{2}{*}{ Employment status } & \multicolumn{3}{|c|}{ Group I (50) } & \multicolumn{3}{c||}{ Group II (50) } \\
\cline { 2 - 8 } & Baseline & $\mathbf{1 2}$ months & $\mathbf{2 4}$ months & Baseline & 12 months & 24 months \\
\hline Employed part-time & 1 & 2 & 1 & 1 & 1 & 1 \\
\hline Employed full-time & 4 & 3 & 4 & 7 & 9 & 9 \\
\hline Unemployed & 1 & 0 & 0 & 2 & 1 & 1 \\
\hline Unemployed due to pain & 1 & 1 & 1 & 1 & 0 & 0 \\
\hline Total Employed & $\mathbf{5}$ & $\mathbf{5}$ & $\mathbf{5}$ & $\mathbf{8}$ & $\mathbf{1 0}$ & $\mathbf{1 0}$ \\
\hline Eligible for employment & 7 & 7 & 7 & 11 & 11 & 11 \\
\hline Housewife & 2 & 2 & 2 & 4 & 4 & 4 \\
\hline Disabled & 30 & 30 & 30 & 18 & 18 & 18 \\
\hline Over 65 year of age & 11 & 12 & 12 & 17 & 17 & 17 \\
\hline Total Number of Patients & $\mathbf{5 0}$ & $\mathbf{5 0}$ & $\mathbf{5 0}$ & $\mathbf{5 0}$ & $\mathbf{5 0}$ & $\mathbf{5 0}$ \\
\hline \hline
\end{tabular}

tion. This is illustrated for all participants with $38 \%$ in Group I and $44 \%$ in Group II at 24 months. However, the data from the successful categories showed improvement in $51 \%$ in Group I and $57 \%$ in Group II.

\section{Employment Characteristics}

Employment characteristics are shown in Table 6.

\section{Opioid Intake}

Results of opioid intake over a period of 2 years are illustrated in Table 7.

\section{Changes in Weight}

Changes in weight over a 2-year period in both groups are illustrated in Table 8.

\section{Adverse Events}

There were no major adverse events reported over a period of 2 years in 100 patients (400 encounters).

\section{Discussion}

The current study of 100 patients with lumbar central spinal stenosis with a 2 year follow-up with per- 
Table 7. Opioid intake (morphine equivalence mg)

\begin{tabular}{|l|c|c||}
\hline \multirow{2}{*}{$\begin{array}{l}\text { Narcotic intake } \\
\text { Morphine Equivalence mg) }\end{array}$} & $\begin{array}{c}\text { Group I } \\
\text { (50) }\end{array}$ & $\begin{array}{c}\text { Group II } \\
\text { (50) }\end{array}$ \\
\cline { 2 - 4 } & Mean \pm SD & Mean \pm SD \\
\hline Baseline & $45.66 \pm 53.0$ & $49.2 \pm 42.2$ \\
\hline 3 months & $33.3^{*} \pm 35.7$ & $33.1^{*} \pm 27.5$ \\
\hline 6 months & $34.4 \pm 43.0$ & $33.7^{*} \pm 34.7$ \\
\hline 12 months & $35.9 \pm 43.1$ & $33.3^{*} \pm 34.5$ \\
\hline 18 months & $35.7 \pm 43.3$ & $33.3^{*} \pm 34.5$ \\
\hline 24 months & $35.7 \pm 43.3$ & $32.5^{*} \pm 34.8$ \\
\hline Group Difference & \multicolumn{3}{|c|}{0.895} \\
\hline Baseline vs follow-up points & \multicolumn{3}{|c|}{0.4012} \\
\hline Group by Time Interaction\# & \multicolumn{3}{|c|}{} \\
\hline
\end{tabular}

* indicates significant difference with baseline values $(\mathrm{p}<0.05)$

\# Group by Time Interaction - There were no significant difference between groups at 3 months, 6 months, 12 months, 18 months and 24 months
Table 8. Characteristics weight monitoring.

\begin{tabular}{|c|c|c|c|}
\hline \multirow{2}{*}{ Weight (lbs) } & Group I (50) & Group II (50) & \multirow{2}{*}{$\begin{array}{c}P \\
\text { value }\end{array}$} \\
\hline & Mean \pm SD & Mean \pm SD & \\
\hline Weight at Beginning & $195 \pm 52.4$ & $187 \pm 47.3$ & 0.419 \\
\hline \multicolumn{4}{|l|}{ At one year } \\
\hline Weight at one year & $193 \pm 53.8$ & $185 \pm 47.4$ & 0.458 \\
\hline Change from baseline & $-2.4 \pm 9.0$ & $-1.8 \pm 8.11$ & 0.728 \\
\hline No change & $24 \%(12)$ & $26 \%(13)$ & \multirow{3}{*}{0.910} \\
\hline Gained weight & $34 \%(17)$ & $30 \%(15)$ & \\
\hline Lost weight & $42 \%(21)$ & $44 \%(22)$ & \\
\hline \multicolumn{4}{|l|}{ At 2 years } \\
\hline Weight at 2 years & $192 \pm 52.8$ & $187 \pm 47.3$ & 0.546 \\
\hline Change from baseline & $-2.9 \pm 9.1$ & $-0.9 \pm 9.2$ & 0.277 \\
\hline No change & $32 \%(16)$ & $26 \%(13)$ & \multirow{3}{*}{0.741} \\
\hline Gained weight & $28 \%(14)$ & $34 \%(17)$ & \\
\hline Lost weight & $40 \%(20)$ & $40 \%(20)$ & \\
\hline
\end{tabular}

sistent, severe, chronic low back and lower extremity pain responded to caudal epidural injections with or without steroids with significant pain relief and functional status improvement in $51 \%$ in Group I with local anesthetic only, and $57 \%$ with local anesthetic and steroids in Group II at the end of 2 years when patients were categorized into successful group with response of at least 3 weeks with first 2 procedures. Overall significant improvement above $50 \%$ was seen in $38 \%$ of the patients in Group I without steroids and $44 \%$ of the patients in Group II with steroids at 2-year follow-up. The procedures for 2 years in the successful category were $5.1 \pm 2.6$ in Group I and $4.5 \pm 2.3$ in Group II with average total relief per two year of $59.6 \pm 40.1$ weeks in Group I and $54.2 \pm 38.8$ weeks in Group II over a period of 104 weeks. However, the overall total relief per 2 years was $44.6 \pm 42.3$ weeks in Group I and $41.5 \pm$ 40.5 weeks in Group II among all participants including the very low response seen in failed participants. Thus, there were no differences between the participants receiving either local anesthetic alone or local anesthetic with steroids. Consequently, the results of this study show that if the response is poor with the first 2 procedures, future treatments will continue to obtain a very poor or no response. Overall, the response is only modest in approximately half of the patients feeling significant improvement half of the time.

The results of this study may not be compared to previous evaluations as there are no other randomized trials available for caudal epidural injections. The results of this study show that with appropriate patient selection and prudent use of repeat injections, longterm relief can be achieved - though modest.

This study is significant for interventional pain management practices, pragmatic, or practical clinical trials, with an active-control measure effectiveness, and so are superior to explanatory trials that measure efficacy $(77,78)$. This is the first large scale study utilizing an active-control design with a follow of 2 years.

The study may face criticism with or without appropriate understanding of the design and the results (4). The study may be criticized for the lack of a placebo group. There are numerous difficulties associated with placebo control which are insurmountable with interventional techniques in the United States. A true placebo, meaning an inactive substance placed in an inactive structure - away from nerves and closed spaces, is not only rare but almost impossible. Further, placebo controlled neural blockade is not realistic and has been widely misinterpreted (25-27,40-46,52-74,79). Multiple authors, specifically methodologists, have mistakenly reported that any local anesthetic injection, which yields similar results as steroids, is considered as placebo $(25-27,40-46,53)$. In contrast, the experimental and clinical evidence shows active response which may yield to inaccuracies, even with sodium chloride solution, along with local anesthetic injection or other substances (80-82). In addition, epidural saline has been 
shown to be active and therapeutic (83-85). However, a proper placebo design has been utilized by Ghahreman et al (86). The numerous interactions with placebo and nocebo effects are misunderstood and inappropriately applied by methodologists $(87,88)$. Further, it would be inconceivable for a placebo effect to last for 2 years, on some occasions in $85 \%$ of the patients, with repeat interventions. Another argument relates to the natural healing process and confounding of the results. However, this has not been the case in these patients as these patients have suffered over long periods of time and were recalcitrant and non-responsive to other modalities of treatments.

It has been clearly shown in numerous studies that local anesthetics and steroids exert analgesic effects by various mechanisms and there may not be significant difference whether steroids are used or not (89-93). However, multiple other substances also have been evaluated in recent years (94-96). Further, in an evaluation by Golish et al (97) showed that presence of a molecular complex of fibronectin and aggrecan predict response to lumbar epidural steroid injections for radiculopathy with herniated nucleus pulposus. They concluded that this biomarker is accurate, objective, and not affected by demographic or psychosocial variables in the small series they published in lumbar disc herniation with radiculitis. No such evaluations have been performed in patients with spinal stenosis and also there are no large scale studies to replicate the data by Golish et al. Multiple complications with epidural steroid injections have been reported which included complications related to the steroids, placement of the needle, injection of various drugs, bleeding, fasting, and infection. However, none of these were observed in this evaluation (98-102).

In summary, the evidence in this evaluation of a randomized, active-controlled trial demonstrates that caudal epidural injections with or without steroids in patients with spinal stenosis with low back and lower extremity pain provide significant pain relief and improvement in functional status at 2-year follow-up.

\section{Conclusion}

This 2-year report of the results of a randomized, double-blind trial of caudal epidural injections with local anesthetic with or without steroids for chronic function-limiting low back pain and lower extremity pain secondary to spinal stenosis has demonstrated pain relief and improvement in functional status in $51 \%$ of participants in local anesthetic group and $57 \%$ in local anesthetic with steroid group in the successful category.

\section{Acknowledgments}

The authors wish to thank Sekar Edem for assistance in the search of the literature, Tom Prigge, MA, for manuscript review, and Tonie M. Hatton and Diane E. Neihoff, transcriptionists, for their assistance in preparation of this manuscript. We would like to thank the editorial board of Pain Physician for review and criticism in improving the manuscript.

\section{References}

1. Haig AJ, Tomkins CC. Diagnosis and management of lumbar spinal stenosis. JAMA 2010; 303:71-72.

2. Kalichman L, Cole R, Kim DH, Li L, Suri P, Guermazi A, Hunter DJ. Spinal stenosis prevalence and association with symptoms: The Framingham Study. Spine J 2009; 9:545-550.

3. Kovacs FM, Urrútia G, Alarcón JD. Surgery versus conservative treatment for symptomatic lumbar spinal stenosis: A systematic review of randomized controlled trials. Spine (Phila Pa 1976) 2011; 36:E1335-E1351.

4. Friedly JL, Bresnahan BW, Comstock B, Turner JA, Deyo RA, Sullivan SD, Heagerty P, Bauer Z, Nedeljkovic SS, Avins AL, Nerenz D, Jarvik JG. Study protocolLumbar Epidural steroid injections for Spinal Stenosis (LESS): A double-blind randomized controlled trial of epidural steroid injections for lumbar spinal stenosis among older adults. BMC Musculoskelet Disord 2012; 13:48.

5. Boden SD, McCowin PR, Davis DO, Dina TS, Mark AS, Wiesel S. Abnormal magnetic resonance scans of the lumbar spine in asymptomatic subjects: A prospective investigation. J Bone Joint Surg Am 1990; 72:403-408.

6. Jensen MC, Brant-Zawadzki MN, Obuchowski N, Obuchowski N, Modic MT, Malkasian D, Ross JS. Magnetic resonance imaging of the lumbar spine in people without back pain. $N$ Engl J Med 1994; 331:69-73.

7. Comer CM, Redmond AC, Bird HA Conaghan PG. Assessment and management of neurogenic claudication associated with lumbar spinal stenosis in a UK primary care musculoskeletal service: A survey of current practice among physiotherapists. BMC Musculoskelet Disord 2009; 10:121.

8. Weinstein JN, Tosteson TD, Lurie JD, Tosteson AN, Blood E, Hanscom B, Herkowitz $H$, Cammisa F, Albert T, Boden SD, Hilibrand A, Goldberg $H$, Berven S, An H; SPORT Investigators. Surgical versus nonsurgical therapy for lumbar spinal stenosis. $N$ Engl J Med 2008; 358:794-810.

9. Cherkin DC, Deyo RA, Loeser JD, Bush T, Waddell G. An international comparison of back surgery rates. Spine (Phila $\mathrm{Pa}$ 1976) 1994; 19:1201-1206.

10. Katz JN, Harris MB. Clinical practice. Lumbar spinal stenosis. $N$ Engl J Med 2008; 358:818-825.

11. Deyo RA, Mirza SK, Martin BI, Kreuter 
W, Goodman DC, Jarvik JG.. Trends, major medical complications, and charges associated with surgery for lumbar spinal stenosis in older adults. JAMA 2010; 303:1259-1265.

12. Chen E, Tong KB, Laouri M. Surgical treatment patterns among Medicare beneficiaries newly diagnosed with lumbar spinal stenosis. Spine ] 2010; 10:588594 .

13. Cummins J, Lurie JD, Tosteson TD, Hanscom B, Abdu WA, Birkmeyer NJ, Herkowitz H, Weinstein J. Descriptive epidemiology and prior healthcare utilization of patients in the Spine $\mathrm{Pa}$ tient Outcomes Research Trial's (SPORT) three observational cohorts: Disc herniation, spinal stenosis, and degenerative spondylolisthesis. Spine (Phila Pa 1976) 2006; 31:806-814.

14. Malmivaara A, Slätis $P$, Heliövaara $M$, Sainio $P$, Kinnunen $H$, Kankare J, Dalin-Hirvonen N, Seitsalo S, Herno A, Kortekangas $P$, Niinimäki T, Rönty $H$, Tallroth K, Turunen V, Knekt P, Härkänen $\mathrm{T}$, Hurri $\mathrm{H}$; Finnish Lumbar Spina Research Group. Surgical or nonoperative treatment for lumbar spinal stenosis? A randomized controlled trial. Spine (Phila Pa 1976) 2007; 32:1-8.

15. Tosteson AN, Lurie JD, Tosteson TD, Skinner JS, Herkowitz H, Albert T, Boden $\mathrm{SD}$, Bridwell K, Longley $\mathrm{M}$, Andersson GB, Blood EA, Grove MR, Weinstein JN; SPORT Investigators. Surgical treatment of spinal stenosis with and without degenerative spondylolisthesis: Cost-effectiveness after 2 years. Ann Intern Med 2008; 149:845-853.

16. Manchikanti L, Cash RA, McManus CD, Pampati V, Fellows B. Fluoroscopic caudal epidural injections with or without steroids in managing pain of lumbar spinal stenosis: One year results of randomized, double-blind, active-controlled trial. J Spinal Disord Tech 2012; 25:226-234.

17. Manchikanti L, Cash KA, McManus CD, Damron KS, Pampati V, Falco FJE. Lumbar interlaminar epidural injections in central spinal stenosis: Preliminary results of a randomized, double-blind, active control trial. Pain Physician 2012; 15:51-63.

18. Park $\mathrm{CH}$, Lee $\mathrm{SH}$, Jung JY. Dural sac cross-sectional area does not correlate with efficacy of percutaneous adhesiolysis in single level lumbar spinal stenosis. Pain Physician 2011; 14:377-382.

19. Lingreen R, Grider JS. Retrospective review of patient self-reported improve- ment and post-procedure findings for MILD (minimally invasive lumbar decompression). Pain Physician 2010; 13:555-560.

20. Briggs VG, Li W, Kaplan MS, Eskander MS, Franklin PD. Injection treatment and back pain associated with degenerative lumbar spinal stenosis in older adults. Pain Physician 2010; 13:E347E355.

21. Yi X, McPherson B. Application of $X$ STOP device in the treatment of lumbar spinal stenosis. Pain Physician 2010; 13:Е327-E336.

22. Manchikanti L, Pampati V, Falco FJE, Hirsch JA. Growth of spinal interventional pain management techniques: Analysis of utilization trends and medicare expenditures 2000 to 2008. Spine (Phila Pa 1976) 2012 July 11 [Epub ahead of print].

23. Manchikanti L, Pampati V, Boswell MV, Smith HS, Hirsch JA. Analysis of the growth of epidural injections and costs in the Medicare population: A comparative evaluation of 1997, 2002, and 2006 data. Pain Physician 2010; 13:199-212.

24. Manchikanti L, Pampati V, Singh V, Boswell MV, Smith HS, Hirsch JA. Explosive growth of facet joint interventions in the Medicare population in the United States: A comparative evaluation of 1997, 2002, and 2006 data. BMC Health Serv Res 2010; 10:84.

25. Staal JB, de Bie R, de Vet HC, Hildebrandt J, Nelemans P. Injection therapy for subacute and chronic low back pain. Cochrane Database Syst Rev. 2008;3:CDoo1824.

26. Chou R, Huffman L. Evaluation and Management of Low Back Pain: Evidence Review. Glenview, IL, American Pain Society, 2009.

27. Manchikanti L, Datta S, Gupta S, Munglani R, Bryce DA, Ward SP, Benyamin RM, Sharma ML, Helm II S, Fellows B, Hirsch JA. A critical review of the American Pain Society clinical practice guidelines for interventional techniques: Part 2. Therapeutic interventions. Pain Physician 2010; 13:E215-E264.

28. Abbott ZI, Nair KV, Allen RR, Akuthota VR. Utilization characteristics of spinal interventions. Spine ] 2012; 1:35-43.

29. Manchikanti L, Pampati V, Cash KA. Protocol for evaluation of the comparative effectiveness of percutaneous adhesiolysis and caudal epidural steroid injections in low back and/or lower extremity pain without post surgery syn- drome or spinal stenosis. Pain Physician 2010; 13:E91-E110.

30. Manchikanti L, Boswell MV, Singh V, Benyamin RM, Fellows B, Abdi S, Buenaventura RM, Conn A, Datta S, Derby R, Falco FJE, Erhart S, Diwan S, Hayek SM, Helm S, Parr AT, Schultz DM, Smith HS, Wolfer LR, Hirsch JA. Comprehensive evidence-based guidelines for interventional techniques in the management of chronic spinal pain. Pain Physician 2009; 12:699-802.

31. Helm S II, Benyamin RM, Chopra P, Deer TR, Justiz R. Percutaneous adhesiolysis in the management of chronic low back pain in post lumbar surgery syndrome and spinal stenosis: A systematic review. Pain Physician 2012; 15:E435-E462.

32. Parr AT, Manchikanti L, Hameed $\mathrm{H}$, Conn A, Manchikanti KN, Benyamin RM, Diwan S, Singh V, Abdi S. Caudal epidural injections in the management of chronic low back pain: A systematic appraisal of the literature. Pain Physician 2012; 15:E159-E198.

33. Benyamin RM, Manchikanti L, Parr AT, Diwan SA, Singh V, Falco FJE, Datta S, Abdi S, Hirsch JA. The effectiveness of lumbar interlaminar epidural injections in managing chronic low back and lower extremity pain. Pain Physician 2012; 15:E363-E404.

34. Manchikanti L, Buenaventura RM, Manchikanti KN, Ruan X, Gupta S, Smith HS, Christo PJ, Ward SP. Effectiveness of therapeutic lumbar transforaminal epidural steroid injections in managing lumbar spinal pain. Pain Physician 2012; 15:E199-E245.

35. Manchikanti L, Cash KA, McManus CD, Pampati V, Singh V, Benyamin RM. The preliminary results of a comparative effectiveness evaluation of adhesiolysis and caudal epidural injections in managing chronic low back pain secondary to spinal stenosis: A randomized, equivalence controlled trial. Pain Physician 2009; 12:E341-E354.

36. Ammendolia C, Stuber K, de Bruin LK, Furlan AD, Kennedy CA, Rampersaud YR, Steenstra IA, Pennick V. Nonoperative treatment of lumbar spinal stenosis with neurogenic claudication: A systematic review. Spine (Phila Pa 1976) 2012; 37:E609-E616.

37. Park DK, An HS, Lurie JD, Zhao W, Tosteson A, Tosteson TD, Herkowitz H, Errico T, Weinstein JN. Does multilevel lumbar stenosis lead to poorer outcomes?: A subanalysis of the Spine Pa- 
tient Outcomes Research Trial (SPORT) lumbar stenosis study. Spine (Phila Pa 1976) 2010; 35:439-446.

38. Fukusaki M, Kobayashi I, Hara T, Sumikawa K. Symptoms of spinal stenosis do not improve after epidural steroid injection. Clin J Pain 1998; 14:148-151.

39. Manchikanti L, Cash KA, McManus CD, Pampati V, Abdi S. Preliminary results of a randomized, equivalence trial of fluoroscopic caudal epidural injections in managing chronic low back pain: Part 4-Spinal stenosis. Pain Physician 2008; 11:833-848.

40. Manchikanti L, Falco FJE, Boswell MV, Hirsch JA. Facts, fallacies, and politics of comparative effectiveness research: Part 1. Basic considerations. Pain Physician 2010; 13:E23-E54.

41. Manchikanti L, Falco FJE, Boswell MV, Hirsch JA. Facts, fallacies, and politics of comparative effectiveness research Part 2. Implications for interventional pain management. Pain Physician 2010; 13:E55-E79.

42. Manchikanti L, Singh V, Boswell MV. Interventional pain management at crossroads: The perfect storm brewing for a new decade of challenges. Pain Physician 2010; 13:E111-E140.

43. Benyamin RM, Datta S, Falco FJE. A perfect storm in interventional pain man agement: Regulated, but unbalanced. Pain Physician 2010; 13:109-116.

44. Chou R, Atlas SJ, Loeser JD, Rosenquist RW, Stanos SP. Guideline warfare over interventional therapies for low back pain: Can we raise the level of discourse? J Pain 2011; 12:833-839.

45. Manchikanti L, Benyamin RM, Falco FJE, Caraway DL, Datta S, Hirsch JA. Guidelines warfare over interventional techniques: Is there a lack of discourse or straw man? Pain Physician 2012; 15:E1E26.

46. Manchikanti L, Datta S, Derby R, Wolfer LR, Benyamin RM, Hirsch JA. A critical review of the American Pain Society clinical practice guidelines for interventional techniques: Part 1. Diagnostic interventions. Pain Physician 2010; 13:E141E174.

47. Kuntz KM, Snider RK, Weinstein JN, Pope $\mathrm{MH}$, Katz JN. Cost-effectiveness of fusion with and without instrumentation for patients with degenerative spondylolisthesis and spinal stenosis. Spine (Phila Pa 1976) 2000; 25:1132-1139.

48. Atlas SJ, Deyo RA, Keller RB, Chapin $A M$, Patrick DL, Long JM, Singer DE.
The Maine Lumbar Spine Study, Part III. 1-year outcomes of surgical and nonsurgical management of lumbar spinal stenosis. Spine (Phila Pa 1976) 1996; 21:17871794.

49. Johnsson KE, Uden A, Rosen I. The effect of decompression on the natural course of spinal stenosis. A comparison of surgically treated and untreated patients. Spine (Phila Pa 1976) 1991; 16:615-619.

50. Mariconda M, Fava R, Gatto A, Longo $C$, Milano C. Unilateral laminectomy for bilateral decompression of lumbar spinal stenosis: A prospective comparative study with conservatively treated patients. J Spinal Disord Tech 2002; 15:3946.

51. Koc Z, Ozcakir S, Sivrioglu K, Gurbet A Kucukoglu S. Effectiveness of physical therapy and epidural steroid injections in lumbar spinal stenosis. Spine (Phila Pa 1976) 2009; 34:985-989.

52. Moher D, Schulz KF, Altman D, for the CONSORT Group. The CONSORT statement: Revised recommendations for improving the quality of reports of parallel-group randomized trials. JAMA 2001; 285:1987-1991.

53. Manchikanti L, Hirsch JA, Smith HS. Evidence-based medicine, systematic reviews, and guidelines in interventional pain management: Part 2. Randomized controlled trials. Pain Physician 2008; 11:717-773.

54. Fairbank JCT, Pynsent PB. The Oswestry Disability Index. Spine (Phila Pa 1976) 2000; 25:2940-2953.

55. Carragee EJ, Chen I. Minimum acceptable outcomes after lumbar spinal fusion. Spine J 2010; 10:313-320.

56. Manchikanti L, Singh V, Cash KA, Pampati V, Datta S. Management of pain of post lumbar surgery syndrome: Oneyear results of a randomized, double double-blind, active controlled trial of fluoroscopic caudal epidural injections. Pain Physician 2010; 13:509-521.

57. Manchikanti L, Singh V, Falco FJE, Cash KA, Pampati V. Evaluation of the effectiveness of lumbar interlaminar epidural injections in managing chronic pain of lumbar disc herniation or radiculitis: A randomized, double-blind, controlled trial. Pain Physician 2010; 13:343-355.

58. Manchikanti L, Cash KA, McManus CD, Pampati V, Benyamin RM. Preliminary results of a randomized, double-blind, controlled trial of fluoroscopic lumbar interlaminar epidural injections in managing chronic lumbar discogenic pain without disc herniation or radiculitis. Pain Physician 2010; 13:E279-E292.

59. Manchikanti L, Singh V, Cash KA, Pampati V, Damron KS, Boswell MV. A randomized, controlled, double-blind trial of fluoroscopic caudal epidural injections in the treatment of lumbar disc herniation and radiculitis. Spine (Phila Pa 1976) 2011; 36:1897-1905.

6o. Manchikanti L, Singh V, Cash KA, Pampati V, Damron KS, Boswell MV. Effect of fluoroscopically guided caudal epidural steroid or local anesthetic injections in the treatment of lumbar disc herniation and radiculitis: $A$ randomized, controlled, double blind trial with a two-year follow-up. Pain Physician 2012; 15:273-286.

61. Manchikanti L, Cash KA, McManus CD, Pampati V, Smith HS. One year results of a randomized, double-blind, active controlled trial of fluoroscopic caudal epidural injections with or without steroids in managing chronic discogenic low back pain without disc herniation or radiculitis. Pain Physician 2011; 14:25-36.

63. Manchikanti L, Cash KA, McManus CD, Pampati V, Benyamin R. Fluoroscopic lumbar interlaminar epidural injections in managing chronic lumbar axial or discogenic pain. J Pain Res 2012; 5:301311.

64. Manchikanti L, Cash KA, McManus CD, Pampati V, Smith HS. Preliminary results of randomized, equivalence trial of fluoroscopic caudal epidural injections in managing chronic low back pain: Part 1. Discogenic pain without disc herniation or radiculitis. Pain Physician 2008; 11:785-800.

65. Manchikanti L, Cash KA, Pampati V, Wargo BW, Malla Y. Cervical epidural injections in chronic discogenic neck pain without disc herniation or radiculitis: Preliminary results of a randomized, double-blind, controlled trial. Pain Physician 2010; 13:E265-E278.

66. Manchikanti L, Cash KA, Pampati V, Malla Y. Fluoroscopic cervical epidural injections in chronic axial or disc-related neck pain without disc herniation, facet joint pain, or radiculitis. J Pain Res 2012; 227-236.

67. Manchikanti L, Cash KA, Pampati V, Wargo BW, Malla Y. The effectiveness of fluoroscopic cervical interlaminar epidural injections in managing chronic cervical disc herniation and radiculitis: Preliminary results of a randomized, double-blind, controlled trial. Pain Physician 2010; 13:223-236. 
68. Manchikanti L, Cash KA, Pampati V, Wargo BW, Malla Y. Management of chronic pain of cervical disc herniation and radiculitis with fluoroscopic cervical interlaminar epidural injections. Int J Med Sci 2012; 9:424-434.

69. Manchikanti L, Malla Y, Cash KA, McManus CD, Pampati V. Fluoroscopic epidural injections in cervical spinal stenosis: Preliminary results of a randomized, double-blind, active control trial. Pain Physician 2012; 15:E59-E70.

70. Manchikanti L, Malla Y, Cash KA, McManus CD, Pampati V. Fluoroscopic cervical interlaminar epidural injections in managing chronic pain of cervical postsurgery syndrome: Preliminary results of a randomized, double-blind active control trial. Pain Physician 2012; 15:1326.

71. Manchikanti L, Cash KA, McManus CD, Pampati V, Benyamin RM. A preliminary report of a randomized double-blind, active controlled trial of fluoroscopic thoracic interlaminar epidural injections in managing chronic thoracic pain. Pain Physician 2010; 13:E357-E369.

72. Manchikanti L, Singh V, Falco FJE, Cash KA, Pampati V, Fellows B. Comparative effectiveness of a one-year follow-up of thoracic medial branch blocks in management of chronic thoracic pain: A randomized, double-blind active controlled trial. Pain Physician 2010; 13:535-548.

73. Manchikanti L, Singh V, Falco FJE, Cash KA, Fellows B. Comparative outcomes of a 2-year follow-up of cervical medial branch blocks in management of chronic neck pain: A randomized, double-blind controlled trial. Pain Physician 2010; 13:437-450.

74. Manchikanti L, Singh V, Falco FJE, Cash KA, Pampati V. Evaluation of lumbar facet joint nerve blocks in managing chronic low back pain: A randomized, doubleblind, controlled trial with a 2-year follow-up. Int J Med Sci 2010; 7:124-135.

75. Pereira J, Lawlor P, Vigano A, Dorgan $M$, Bruera E. Equianalgesic dose ratios for opioids. A critical review and proposals for long-term dosing. J Pain Symptom Manage 2001; 22:672-687. Narcotic analgesic converter, Global-RPh Inc. www.globalrph.com/narcotic.cgi

76. Helsa PE, Breivik $\mathrm{H}$. Epidural analgesia and epidural steroid injection for treatment of chronic low back pain and sciatica. Tidsskr Nor Laegeforen 1979; 99:936939.
77. Tunis SR, Stryer DB, Clancy CM. Practical clinical trials. Increasing the value of clinical research for decision making in clinical and health policy. JAMA 2003; 290:1624-1632.

78. International Conference on Harmonisation of Technical Requirements for Registration of Pharmaceuticals for Human Use. ICH Harmonised Tripartite Guideline. Choice of Control Group and Related Issues in Clinical Trials E1o. July 20, 2000.

79. Smuck M, Levin JH. RE: Manchikanti L, Singh V, Falco FJE, Cash KA, Fellows B. Cervical medial branch blocks for chronic cervical facet joint pain: A randomized double-blind, controlled trial with one-year follow-up. Spine (Phila Pa 1976) 2008; 33:1813-20. Spine (Phila Pa 1976) 2009; 34:1116-1117.

8o. Pham Dang C, Lelong A, Guilley J, Nguyen JM, Volteau C, Venet G, Perrier C, Lejus C, Blanloeil Y. Effect on neurostimulation of injectates used for perineural space expansion before placement of a stimulating catheter: Normal saline versus dextrose $5 \%$ in water. Reg Anesth Pain Med 2009; 34:398-403.

81. Tsui BC, Kropelin B, Ganapathy S, Finucane B. Dextrose $5 \%$ in water: Fluid medium maintaining electrical stimulation of peripheral nerve during stimulating catheter placement. Acta Anaesthesiol Scand 2005; 49:1562-1565.

82. Indahl A, Kaigle AM, Reikeräs $\mathrm{O}$, Holm $\mathrm{SH}$. Interaction between the porcine lumbar intervertebral disc, zygapophysial joints, and paraspinal muscles. Spine (Phila Pa 1976) 1997; 22:2834-2840.

83. Carette $S$, Leclaire R, Marcoux $S$, Morin F, Blaise GA, St-Pierre A, Truchon R, Parent F, Levesque J, Bergeron V, Montminy $\mathrm{P}$, Blanchette $\mathrm{C}$. Epidural corticosteroid injections for sciatica due to herniated nucleus pulposus. N Engl J Med 1997; 336:1634-1640.

84. Bhatia MT, Parikh LC). Epidural saline therapy in lumbo-sciatic syndrome. J Indian Med Assoc 1966; 47:537-542.

85. Iversen T, Solberg TK, Romner B, Wilsgaard T, Twisk J, Anke A, Nygaard O, Hasvold T, Ingebrigtsen T. Effect of caudal epidural steroid or saline injection in chronic lumbar radiculopathy: Multicentre, blinded, randomised controlled trial. BM] 2011; 343:d 5278 .

86. Ghahreman A, Ferch R, Bogduk N. The efficacy of transforaminal injection of steroids for the treatment of lumbar radicular pain. Pain Med 2010; 11:1149-
1168.

87. Manchikanti L, Giordano J, Fellows B, Hirsch JA. Placebo and nocebo in interventional pain management: $A$ friend or a foe - or simply foes? Pain Physician 2011; 14:E157-E175.

88. Louhiala P, Puustinen R. Rethinking the placebo effect. J Med Ethics 2008; 34:107109.

89. Byrod G, Otani K, Brisby H, Rydevik B, Olmarker K. Methylprednisolone reduces the early vascular permeability increase in spinal nerve roots induced by epidural nucleus pulposus application. J Orthop Res. 2000;18:983-987.

9o. Hayashi N, Weinstein JN, Meller ST, Lee HM, Spratt KF, Gebhart GF. The effect of epidural injection of betamethasone or bupivacaine in a rat model of lumbar radiculopathy. Spine (Phila Pa 1976) 1998; 23:877-885.

91. Pasqualucci A, Varrassi G, Braschi A, Peduto VA, Brunelli A, Marinangeli $F$, Gori F, Colò F, Paladín A, Mojoli F. Epidural local anesthetic plus corticosteroid for the treatment of cervical brachial radicular pain: Single injection verus continuous infusion. Clin J Pain 2007; 23:551-557.

92. Sato C, Sakai A, Ikeda Y, Suzuki H, Sakamoto A. The prolonged analgesic effect of epidural ropivacaine in a rat model of neuropathic pain. Anesth Analg 2008; 106:313-320.

93. Tachihara H, Sekiguchi M, Kikuchi S, Konno S. Do corticosteroids produce additional benefit in nerve root infiltration for lumbar disc herniation. Spine (Phila Pa 1976) 2008; 33:743-747.

94. Amr YM. Effect of addition of epidural ketamine to steroid in lumbar radiculitis: one-year follow-up. Pain Physician 2011; 14:475-481.

95. Cohen SP, White RL, Kurihara C, Larkin TM, Chang A, Griffith SR, Gilligan C, Larkin R, Morlando B, Pasquina PF, Yaksh TL, Nguyen C. Epidural steroids, etanercept, or saline in subacute sciatica: A multicenter, randomized trial. Ann Intern Med 2012; 156:551-559.

96. Ohtori S, Miyagi M, Eguchi Y, Inoue G, Orita S, Ochiai N, Kishida S, Kuniyoshi K, Nakamura J, Aoki Y, Ishikawa T, Arai G, Kamoda H, Suzuki M, Takaso M, Furuya T, Toyone T, Takahashi K. Epidural administration of spinal nerves with the tumor necrosis factor-alpha inhibitor, etanercept, compared with dexamethasone for treatment of sciatica in patients 
with lumbar spinal stenosis: A prospective randomized study. Spine (Phila Pa 1976) 2012; 37:439-444.

97. Golish SR, Hanna LS, Bowser RP, Montesano PX, Carragee EJ, Scuderi GJ. Outcome of lumbar epidural steroid injection is predicted by assay of a complex of fibronectin and aggrecan from epidural lavage. Spine (Phila Pa 1976) 2011; 36:1464-1469.

98. Even JL, Crosby CG, Song Y, McGirt MJ, Devin CJ. Effects of epidural steroid injections on blood glucose levels in pa- tients with diabetes mellitus. Spine (Phila Pa 1976) 2012; 37:E46-E5O.

99. Manchikanti L, Malla Y, Wargo BW, Cash KA, McManus CD, Damron KS, Jackson SD, Pampati V, Fellows B. A prospective evaluation of bleeding risk of interventional techniques in chronic pain. Pain Physician 2011; 14:317-329.

100. Manchikanti L, Malla Y, Wargo BW, Cash KA, Pampati V, Fellows B. A prospective evaluation of complications of 10,000 fluoroscopically directed epidural injections. Pain Physician 2012; 15:131-140.
101. Manchikanti L, Malla Y, Wargo BW, Fellows B. Preoperative fasting before interventional techniques: Is it necessary or evidence-based? Pain Physician 2011; 14:459-467.

102. Manchikanti L, Malla Y, Wargo BW, Fellows B. Infection control practices (safe injection and medication vial utilization) for interventional techniques: Are they based on relative risk management or evidence? Pain Physician 2011; 14:425434 . 